7. Соколовський В.Л. Громадська безпека як об’єкт злочину: дис. ... канд. юрид. наук : 12.00.08. Київ, 2017. 262 с.

8. Japanese Gun Control by David B Kopel. URL: http:// www.guncite.com/-journals/dkjgc.html. (дата звернення 01.02.2021).

DOI https://doi.org/10.30525/978-9934-26-040-7-50

\title{
ЩОДО ЗАБЕЗПЕЧЕННЯ ПРАВА НА ПРАВОВУ ДОПОМОГУ У ФІНЛЯНДІЇ
}

\author{
Боровик А. В. \\ кандидат юридичних наук, дочент, \\ професор кафедри кримінально-правових \\ та адміністративно-правових дисииплін, \\ декан юридичного факультету \\ Міжнародного економіко-гуманітарного університету імені академіка \\ Степана Дем'янчука \\ м. Рівне, Україна
}

Однією з країн де створена дієва система правової допомоги у кримінальних провадженнях, у тому числі корупційних є Фінляндія. Витоки фінської системи правової допомоги сягають у 50-ти роки XX століття. У 1956 році у Фінляндії набув чинності закон про безкоштовну правову допомогу, його метою було надати громадянам правову допомогу, у вигляді представництва їх інтересів в судах приватними адвокатами, але за державний рахунок [1]. Наступний Закон Фінляндії про право на безкоштовний судовий розгляд та перший муніципальний закон про правову допомогу набули чинності в 1973 році, розширили сферу безоплатної процедури та створили комунальні бюро правової допомоги [2]. Ця реформа створила діючу змішану модель, за якою правову допомогу стали надавати і адвокати 3 питань державної правової допомоги, що працювали у державних бюро правової допомоги (Public Legal Aid (PLA)), а також приватні адвокати послуги яких у вказаній сфері сплачувала держава. Головною причиною створення комунальних бюро правової допомоги було надання безоплатної правової допомоги по всій країні. 
Наприкінці 1980-х років Закон про правову допомогу Фінляндії був переглянутий, зміни, що були в нього внесені, розширили право на безоплатну правову допомогу, охопивши багато позасудових цивільних справ, особливо тих, які стосувалися розлучення та опіки над дітьми, а також попереднього розслідування кримінальних справ.

У Фінляндії державна правова допомога регулюється низкою нормативно-правових актів, крім Закону про правову допомогу ще Законом про державні органи правової допомоги та трьома урядовими постановами: одна про правову допомогу, друга про критерії плати за юридичну допомогу та третя про державні бюро правової допомоги [3]. Правова допомога здійснюється Міністерством юстиції та надається переважно через державні органи правової допомоги або за рішеннями судів. У службах правової допомоги у Фінляндії працюють як державні, так і приватні адвокати.

Адвокатів, зайнятих у відділах державної правової допомоги, називають адвокатами 3 питань державної правової допомоги. Вимоги до участі в посаді адвоката 3 питань державної правової допомоги - це ступінь магістра права та належний досвід адвокатської діяльності чи судового розгляду. Більшість адвокатів 3 питань державної правової допомоги мають звання заступника судді (of varatuomari), що означає, що вони пройшли стажування в окружному суді та отримали кваліфікацію судді. Адвокати з питань державної правової допомоги призначаються провідним адвокатом 3 питань державної правової допомоги. Провідні державні адвокати з питань правової допомоги призначаються міністром юстиції [4].

Офіси державної правової допомоги працюють однаково незалежно від їх географічного розташування і їх головним завданням $\epsilon$ надання широкого спектру юридичних послуг, починаючи від юридичного консультування і закінчуючи судовим представництвом. Відповідно до системи правової допомоги, адвокати 3 питань державної правової допомоги, які працюють в офісах державної правової допомоги, надають усі види правової допомоги, від представництва в судах до позасудових процедур, таких як складання документів та юридичних консультацій, тоді як приватні адвокати можуть представляти клієнтів в рамках правової допомоги лише під час судового розгляду.

Надання правової допомоги приватними юристами повинна бути спочатку схвалена рішенням про надання правової допомоги від офісу державної правової допомоги, після чого вони виплачуються 3 державних коштів. Правова допомога надається в основному у всіх випадках, коли існує потреба у правовій допомозі, за винятком випадків незначного значення, таких як безспірні розлучення, або кримінальних справ, де передбачається лише штраф. Юридична 
допомога або безкоштовна, або частково субсидується державою і не доступна компаніям або корпораціям [5].

Система правової допомоги у Фінляндії на сучасному етапі зазнає серйозних структурних змін. Частково це спричинено збільшенням міграції із сільської місцевості до міст, а частково бажанням зробити систему ще ефективнішою. Незважаючи на те, що кількість служб правової допомоги в останні роки скоротилася, більшість із них були не ліквідовані, а реорганізовані у відділення інших служб. Однак така реформа не позбавлена недоліків. Одна служба правової допомоги може представляти лише одну сторону у спорі. Іншому одержувачу правової допомоги може бути важко знайти інший офіс або приватного спеціаліста в розумній близькості для розгляду справи. Сільські райони не є привабливими місцями для проживання молодих юристів тому сільські об'єднання фахівців з правової допомоги починають страждати від недостатньої кількості молодих спеціалістів [6].

Таким чином, однією з фінських проблем $є$ те, як надати правову допомогу у більш віддалених сільських районах.

Крім вказаного, 31 січня 2014 року для юридичної діяльності в Фінляндії були встановленні додаткові обмеження, так приватні адвокати, які не є членами адвокатських спілок, повинні будуть отримати спеціальний дозвіл на надання правової допомоги, зрозуміло, що такі обмеження негативно відобразились на процес надання правової допомоги. В державних службах правової допомоги створилися великі черги і хоча вони мають фактичну монополію на позасудовий режим 3 консультування та допомоги, кількість розглянутих справ з боку служб правової допомоги зменшується [6].

Спектр ініціатив щодо правової допомоги у Фінляндії $є$ дещо вузьким. Немає юридичних клінік чи параюристів, які пропонують допомогу у вирішенні юридичних проблем заявників. Однак багато профспілок пропонують своїм членам послуги 3 надання правової допомоги 3 питань трудового законодавства, включаючи це у вартість членського внеску. Профспілки надають юридичну допомогу своїм членам, якщо між працівниками та роботодавцями виникають суперечки. Роль профспілок у справах про трудове право може бути досить значною, оскільки близько трьох з чотирьох фінів працездатного віку належать до профспілок [7]. У Фінляндії правову допомогу надають різні омбудсмени. Сюди входять парламентський омбудсмен, омбудсмен 3 питань меншин, омбудсмен 3 питань рівності, омбудсмен 3 питань захисту прав споживачів, омбудсмен із захисту даних, омбудсмен 3 питань пацієнтів та омбудсмен із соціального забезпечення. 
Отже, у Фінляндії правова допомога передбачає надання фізичним особам можливості отримати допомогу з юридичних питань повністю або частково за рахунок держави. Однак правова допомога, як правило, не надається, якщо заявник має поліс страхування судових витрат, що охоплює розглянуте питання. У кримінальному провадженні підсудний за певних обставин забезпечується державним захисником за рахунок держави, незалежно від його матеріального стану. Потерпілому від тяжких насильницьких злочинів або статевих злочинів може бути наданий судовий захист за рахунок держави, незалежно від його матеріального стану. Правова допомога не доступна компаніям або корпораціям - тільки людина може їі отримати.

Щоб вирішити вищезазначені проблеми, Міністерство юстиції Фінляндії дедалі більше інвестує в електронні послуги та віддалені послуги. Реформа підкреслює, що, з точки зору громадянина, поточною проблемою $є$ пошук правильної послуги та можливість оцінки ії̈ якості та надійності [8]. Особлива увага приділяється своєчасному наданню послуг з надання правової допомоги та запобіганню ескалації правових проблем, що саме $\epsilon$ важливою складовою зусиль держави щодо стримування витрат [9]. У першій хвилі цих нетрадиційних моделей обслуговування було згадане вище загальнонаціональне телефонне консультування, запроваджене в 2009 році. Зараз акцент робиться на відеоконсультуванні, онлайн-бронюванні зворотних дзвінків юристів державних бюро правової допомоги, допомозі клієнтам через онлайнчати та запуску електронна система подання заявок [8].

Згідно з планами Міністерства юстиції Фінляндії, в майбутньому більша частина витрат на правову допомогу буде покриватися за рахунок внесків клієнтів. Хоча для цього немає конкретного плану, це, по суті, означало б підвищення поточного збору за юридичну допомогу (в даний час 70 євро на клієнта) або зміна сфер в яких передбачена правова допомога [8]. Міністерство юстиції Фінляндії також періодично переглядає критерії розгляду справ про правову допомогу, щоб визначити, чи не можуть деякі правові проблеми більше не мати права на правову допомогу.

Отже, досвід Фінляндії показав, що надання права на професійну правничу допомогу це динамічний процес, де критерії надання постійно переглядаються та узгоджується із сучасними вимогами. Також, на нашу думку, використання цифрових технологій та нетрадиційних моделей обслуговування (наприклад, відеоконсультування, онлайн-зворотні дзвінки юристів державних бюро правової допомоги, онлайн-чати, електронна система подання заявок) покращує доступність до правосуддя взагалі та вказаного права - зокрема. 


\section{Література:}

1. Jokela, A. Oikeudenkäyntikulut ja maksuton oikeusapu. Lakimiesliiton kustannus: Helsinki, 1995.

2. Rosti, H., Niemi, J., \& Lasola, M. Legal Aid and Legal Services in Finland. Research report 237. Helsinki: National Research Institute of Legal Policy, 2008.

3. Ministry of Justice Finnish, 2020. Режим доступу: URL: https://oikeusministerio.fi/en/search?q=legal\%20aid Дата звернення 12.02.2021.

4. Public Legal Aid Attorney. Ministry of Justice, 2013 Режим доступу: URL: https://oikeus.fi/oikeusapu/en/index/oikeusavustaja/publiclegalaidattorney.html. Дата звернення 12.02.2021.

5. Rissanen A. Legal Aid in Finland. In: Halvorsen Rønning O., Hammerslev O. (eds) Outsourcing Legal Aid in the Nordic Welfare States. Palgrave Macmillan, Cham, 2018. Режим доступу: URL: https:// doi.org/10.1007/978-3-319-46684-2_4. Дата звернення 16.02.2021.

6. Barendrecht, Maurits, Laura Kistemaker, Henk Jan Scholten, Ruby Schrader, Marzena Wrzesinska. Legal Aid in Europe: Nine Different Ways to Guarantee Access to Justice? WODC, Ministerie van Veiligheid en Justitie, 2014. Режим доступу: URL: https://www.hiil.org/wp-content/ uploads/2018/09/Legal-Aid-in-Europe-Full-Report.pdf Дата звернення 16.02.2021.

7. Johnsen, J. T. How do the private professions in Finland and Norway impact on legal aid delivery? In A. Uzelac \& C. H. van Rhee (Eds.), The landscape of legal professions in Europe and the USA: Continuity and change. Cambridge: Intersentia, 2011.

8. Oikeusavun kokonaissuunnitelma. Ministry of Justice, Finland, 2015. Режим доступу: URL: https://julkaisut.valtioneuvosto.fi/bitstream/ handle/10024/76608/omso_41_2015_oik_avun_kokonaiss_66s.pdf. Дата звернення 16.02.2021.

9. Buck, A., Pleasence, P., \& Balmer, N.J. (2008, October). Do citizens know how to deal with issues? Some empirical insights. Journal of Social Policy, 37(4), Pp. 661-681. 